\title{
Näkökulmia aikuisuuteen ja aikuiskasvatukseen
}

\author{
Leena Koski ja Erja Moore
}

\author{
Käsitteellä aikuisuus on erilainen sisältö riippuen siitä, \\ tarkoitammeko kulttuurista aikuisuutta, juridista \\ aikuisuutta, aikuisuutta moraalin ja vastuun \\ näkökulmasta tai elämänmittaiseen oppijan rooliin \\ asettuvaa "uutta aikuisuutta". Koulutuksessa aikuisuus \\ on aina määritelty erillisenä. Nykyisin on kuitenkin \\ perusteltua kysyä, miten aikuiskasvatuksen aikuis- \\ etuliite eriyttää aikuiskasvatusta omaksi alueekseen.
}

A vikis ikuisuus on käsite, joka määrittää aikuiskasatuksen kasvatustieteiden kentässä omaksi erilliseksi tutkimusalakseen ja käytännön toiminnakseen. Vuonna 1971 ensimmäisen osamietintönsä jättänyt aikuiskoulutuskomitea pyrki aikuiskasvatuksen ja -koulutuksen määritelmien sisällä ottamaan kantaa myös siihen, kuka on aikuinen aikuiskasvatuksellisessa mielessä. Lähtökohtaisesti aikuisiksi katsottiin henkilöt, "jotka tavallisesti toimivat tai ovat toimineet työelämässä“. Komitea painotti kuitenkin, että työelämä ei ole ainoa aikuiskoulutusta muusta koulutuksesta erottava tekijä, sillä aikuiskoulutukseen katsottiin esimerkiksi kuuluvan myös kouluopintojen aikuissovellukset ja "joidenkin tavanmukaisen kouluiän sivuuttaneiden erityisryhmien, kuten perheenemäntien ja invalidien“ opintojen järjestäminen. (Komiteanmietintö 1971, 89.) Aikuiskoulutuskomitean lähtökohta, yksilön työelämäkiinnitys asettui komitean määritelmien päälähtökohdaksi, jota edelleen korostettiin komitean toisessa osamietinnössä: "Aikuisuuden tärkein tunnuspiirre tässä yhteydessä on työntekijän rooli ja / tai aikuisten muut sosiaaliset roolit: ikä on toissijainen, vaikka ei suinkaan merkityksetön tekijä.“ (Komiteanmietintö 1975, 12.)
Oppivelvollisuusiän jälkeistä ja koulujärjestelmän ulkoista opetusta alettiin nimetä aikuiskasvatukseksi tultaessa 1960-luvulle. "Kansan“ ja "sivistyksen" vaihtuminen "aikuiseksi" ja "kasvatukseksi" kiinnittyi ajan yhteiskunnallisiin murroksiin, modernin, demokraattisen hyvinvointivaltion syntyyn sekä kansainvälisiin vaikutteisiin (ks. esim. Tuomisto 1991). Nykyisessä merkityksessään käsitteet aikuiskasvatus, aikuiskoulutus ja aikuisopiskelija vakiinnutettiin 1960- ja 1970 -lukujen taitteessa, jolloin sekä koulutusjärjestelmä että tavat kouluttautua olivat erilaiset kuin nyt. Peruskoulutusajat olivat nykyistä lyhyempiä, työelämään siirryttiin nuorempina ja yhteiskunnassa oli "perheenemäntien“ kaltaisia ryhmiä, jotka olivat vailla ammatillista koulutusta ja asemaa työmarkkinoilla. Kulttuurisesti "nuoren“ ja "aikuisen" roolien ja tehtävien välillä oli nykyistä selkeämpi ero, ja aikuisuus asettui sekä institutionaalisesti että kokemuksellisesti omaksi, varsin selkeästi rajautuvaksi elämänvaiheekseen. 1960- ja 70-lukujen taitteessa aikuiskoulutus alettiin myös nähdä tärkeäksi hyvinvointivaltiollisten rakenteiden osaksi mekanismina, joka sääntelee taloudellisten suhdanteiden vaihtelujen yksilöllisiä ja yhteiskunnallisia seurauksia. 
Aikuisuus näyttää muuttuneen tai tulleen kyseenalaiseksi jälkimodernin yhteiskunnan murroksissa (esim. Nikander 1999; Antikainen, Rinne ja Koski 2000, 336). Myös aikuiskoulutuksen asema ja tehtävät ovat muotoutuneet uudenlaisiin lähtökohtiin. Hyvinvointivaltion sosiaalinen sääntely ja aikuiskoulutukselle asetetut keskeiset tavoitteet kuten koulutuksellinen tasaarvo ovat liudentumassa yksilöllisiin ja markkinaperusteisiin tavoitteisiin. Tietoyhteiskunnan kehittämisvisioissa nykyinen aikuisväestö näyttää tietotekniikan käyttöönottoa ajatellen lähinnä vajaakykyiseltä koulutuksellisten toimenpiteiden kohteelta (esim. Kansallinen ikäohjelma 2000). Elinikäisen oppimisen ja oppimisyhteiskunnan ideaaleissa aikuisuus puolestaan näyttää saavan keskeisesti yhteisöjen ja yksilöiden valtautumiseen liittyviä sisältöjä.

Aikuisuuden asettuminen aikuisten koulutuksen ja kasvatuksen muuttuvaan kontekstiin näyttää monin tavoin problematisoituneen. Tässä artikkelissa tarkastellaan aikuisuutta lähtien kulttuurisista, juridisista, kehityspsykologisista ja koulutusjärjestelmään rakennetuista määrityksistä. Pohdimme sitä, miten erilaiset aikuisuuden sisällöt asettuvat tämänhetkiseen keskusteluun koulutuksesta, kulttuurista, työvoimasta ja elämän vaiheistumisesta. Millaisia aikuisuuksia eri lähtökohdista syntyy? Artikkelin taustalla ovat ajatukset niin kulttuuria ja työmarkkinoita koskevista muutoksista kuin esimerkiksi nykyisin käytettyjen koulutusluokitusten, kuten jako aikuiskoulutukseen ja koulujärjestelmäkoulutukseen, ongelmallisuudesta vallitsevien opiskelukäytäntöjen ja aikuisuuden moniulotteisuuden kuvaamisessa. Mitä aikuisuus -käsite merkitsee toisaalta aikuiskasvatuksen ja -koulutuksen määrittymiselle ja toisaalta yksilöiden tavoille mieltää oma suhteensa aikuisuuteen? Käsitemäärittelyjen lisäksi esitämme empiirisen aineiston ${ }^{1}$ valossa joitakin alustavia havaintoja yksilöiden aikuisuutta koskevista pohdinnoista.

\section{Kultturinen aikuisuus}

$\mathrm{H}$ ampurin aikuiskasvatusjulistuksessa todetaan, että aikuiskasvatus sisältää kaikkine jatkuvat muodollisetja epävirallisetoppimisprosessit,joiden kautta yhteiskunnan aikuisina pitämät ihmiset kehittävät kykyjään (Toiviainen 1997, 186). Tämä määritys korostaa aikuisuuden käsitteellistä ja sisällöllistä kulttuurisidonnaisuutta. Kulttuurisesti yksinkertaisimmillaan aikuisuus viittaa ikään, ja aikuisuuden yhteydessä yleisimmin puhutaan täysi-ikäisyydestä ja täysikasvuisuudesta. Täysiikäisyys ikäkriteerinä on problemaattinen: se voi vaihdella maittain, eikä sitä teollistuneitten maiden ulkopuolella välttämättä edes määritellä, vaan se voi liittyä paikalliseen kulttuuriperintöön, eriytyä sukupuolittain ja jopa yksilöittäin (Tight 1996).

Länsimaisissa kulttuureissa, joissa yleisesti katsotaan ihannoitavan ja idealisoitavan nuoruutta, aikuisuus näyttää asettuvan ihanteen peiliksi, jonkinasteiseksi käänteistilaksi. Nuoruus edustaa modernin yhteiskunnan haluttuja ominaisuuksia: kasvua, eteenpäin suuntautuneisuutta, terveyttä, voimaa ja kauneutta. Aikuisuus puolestaan ilmentää alkavaa voimien heikkenemistä, terveyden rapautumista, naisellisen kauneuden (ja miehisen komeuden?) menettämistä ja pysähtyneisyyttä mutta myös uudenlaista energisyyttä ja ymmärrystä. Nuorten puheissa aikuisuus 
tarkoittaa "jämähtämistä“ paikoilleen, luutuneita käsityksiä ja norminvartiointia (esim. Harinen 2000). Samaa kaksinaisuutta kuvaa julkinen aikuisuuspuhe esimerkiksi aikakauslehdistössä, jossa aikuisuutta kuvataan "minä aikuinen" -teemalla - se on uudenlainen voimavara joka legitimoidaan nuorekkuutta korostamalla. 40-vuotias voi Virve Rostin tapaan sanoa elävänsä seesteistä aikaa monista muutoksista selvinneenä, mutta silti olla tuntematta itseään "tippaakaan keski-ikäiseksi“ (Ilta-Sanomat 27.5.2000). Vilkko (1997) kuitenkin väittää, että aikuisuutta luonnehtivat sellaiset määreet kuin keskeneräisyys, puutteellisuus, epävarmuus ja uudelleen aloittamiset.

Aikuisuus kohdistuu kulttuurisesti eri tavoin myös miehiin ja naisiin. Esimerkiksi kansan keskuudessa on vakiintuneita sanontoja, kuten "pojat ovat aina poikia" tai "miehet eivät koskaan kasva aikuisiksi“. Nämä kuvastanevat kulttuurisia käsityksiä sukupuolten välisistä eroista suhteessa aikuisuuteen - ajatuksena näyttää olevan, että miehet pysyvät lapsenkaltaisesti luovina, normeja rikkovina seikkailijoina (ja vastuuttomina?) myös vanhetessaan toisin kuin naiset, jotka näin näyttävät asettuvan pysähtyneeseen vastuullisuuteen. Kuitenkin esimerkiksi Aapola (1999, 340) osoittaa, että aikuisen naisen asema on kulttuurisesti varsin ambivalentti. Naisten on miehiä vaikeampaa saavuttaa sosiaalisesti itsenäisen aikuisen asemaa. Naisia määritellään herkemmin suhteessa toisiin ihmisiin, erityisesti miehiin, vaimoiksi, äideiksi ja tyttäriksi. Toisaalta tilastot osoittavat, että tytöt itsenäistyvät ja lähtevät kotoa aikaisemmin kuin pojat. Yli puolet tytöistä on lähtenyt kotoa 20-vuotiaina, pojista vasta 22 vuotiaana. Mielenkiintoinen kulttuurinen piirre Suomessa on myös käsite "aikamiespoika“. Suomessa on 7800030 vuotta täyttänyttä lapsuudenperheessään asuvaa henkilöä, joista neljä viidestä on miehiä. (Tilastokeskus 1999a.)

\section{Juridinen ja virallinen aikuisu us}

$\mathrm{K}^{\mathrm{s}}$ ulttuuriset käsitykset aikuisuudesta ovat yksilöiden identiteettimuodostuksen aineksia. Niiden merkitys näyttää kuitenkin vähäiseltä, kun aikuisuutta määritetään juridisesti koulutukseen ja työelämään liittyvänä käsitteenä. Lainsäädännöllisesti jokainen Suomen kansalainen saavuttaa taloudellista ja oikeudellista täysivaltaisuutta tarkoittavan täysi-ikäisyyden täyttäessään 18 vuotta. Perustuslaillisesti yksilö tulee tällöin itsestään ja toisista sekä yhteiskunnan toiminnasta vastuulliseksi aikuiskansalaiseksi. Työelämässä ja koulutuksessa on kuitenkin käytössä säädöksiä, joissa täysivaltaisuus ja riippumattomuus vanhemmista saavutetaan vasta myöhemmällä iällä. Itsenäinen täysivaltaisuus 18-vuotiaana todentuu vain siinä tapauksessa, että yksilö on itse hankituin tai perityin taloudellisin varoin saavuttanut sellaisen aseman, että ei tarvitse sosiaalivaltiollisia palveluja. Muussa tapauksessa lainsäädäntö asettaa 18-25 -vuotiaat kansalaiset joko riippuvaisiksi vanhemmistaan tai normatiivisesti asetetusta suhteesta koulutus- ja työmarkkinoihin.

Aikuisuuden määrittymistä työmarkkinoilla voi hakea esimerkiksi siitä, kuka on oikeutettu työmarkkinatukeen. 18-24 -vuotiaalla ei ole oikeutta työmarkkinatukeen, jos hän on ilman hyväksyttävää syytä kieltäytynyt tarjotusta työstä tai ... koulutuksesta, työharjoittelusta, työkokeilusta tai kuntoutuksesta taikka kieltäytynyt, eronnut tai jättänyt hakeutumatta hänelle soveltuvaan ammatilliseen koulutukseen (L 665/1996). Itsenäisen, aikuisen työmarkkinakansalaisen aseman saavuttaa siis iän perusteella 25 -vuotiaana, sitä aiemmin tekemällä työtä työsuhteessa tai hakeutumalla koulutukseen. Opintotukilaissa (L 65/1994) täysivaltaisen aikuisuuden rajoja määritetään kysymyksenä siitä, asuuko opiskelija vanhempiensa kotona vai itsenäisesti.

$\mathrm{O}$ pintotukijärjestelmässä on myös erityinen asema aikuisopiskelijalle - mahdollisuus tavallisesta opintotuesta poikkeavan aikuisopintotuen saamiseen. Aikuisopintorahaa hakevan tulee olla iältään 30-54-vuotias. Myös aikuisopintorahan saamisen edellytyksenä on kiinnitys työelämään, koskapa aikuisopintorahaa hakevalla on oltava työ- tai virkasuhde, josta hän on vapaalla. Työtönkin voi olla oikeutettu aikuisopiskelijan asemaan, mikäli hänen työttömyytensä on kestänyt alle vuoden ja taustalta löytyy vähintään 
vuoden pituinen työsuhde. (www.kela.fi 2000.) Juridisesti aikuisuuden sosiaalivaltiollisiin tukiin kiinnittyvät määrittelyt näyttävät asettuvan samaan ajatteluun kuin aikuiskoulutuskomitean I osamietinnön lähtökohta: aikuinen on henkilö, joka vastaa (tai on ennen koulutukseen tuloaan vastannut) omasta toimeentulostaan tekemällä työtä. Samanaikaisesti ikävuosien toisessa päässä täysikykyisen työmarkkina-aikuisuuden ikärajaa ollaan laskemassa, sillä erityisesti työterveydenhuollossa on vakiintunut ajattelu, jonka mukaan yli 45-vuotias työntekijä kuuluu ikääntyvään työvoimaan, johon täytyy alkaa kohdistaa erityistoimenpiteitä työkyvyn ylläpitämiseksi. Mielenkiintoista on kuitenkin muistaa, että käytössä olevissa tilastoluokitteluissa työvoimaan kuuluvat 15-74-vuotiaat (www.stat.fi 2000). Työelämän käytäntöjen erityisenä ongelmana nähdään myös työväestön "karkaaminen“ eläkkeelle ennen aikojaan. Vain harva työskentelee yleiseen vanhuuseläkeikään asti, joka useimmilla aloilla on 65 vuotta. Vuonna 1998 työvoimaan kuului 55-64-vuotiaista vajaa puolet, 42 prosenttia (Tilastokeskus 1999b, 83).

Tilastokeskuksen käyttämät, väestön ikää koskevat luokitukset perustuvat YK:n alustavaan suositukseen vuodelta 1982. Yhtenä luokitusperusteena on ns. ikäkausiluokitus, jossa 14-vuotiaita ja sitä nuorempia kutsutaan termillä lapset, 1524-vuotiaat ovat nuoria, 25-44-vuotiaat aikuisia, 45-64-vuotiaat keski-ikäisiä ja 65 vuotta täyttäneet vanhuksia. (www.stat.fi 2000.) Eri yhteyksissä kuitenkin käytetään näistä luokituksista poikkeavia ikäluokituksia erottamaan nuoruutta aikuisuudesta. Ehkä yleisin rajanveto nuoruuden ja aikuisuuden välillä on tehty niin, että nuoria ovat ihmiset, jotka ovat iältään alle 30vuotiaita (esim. Nuorisobarometri 1/1999; Harinen 2000, 50). Toisaalta vanhusväestön luokittelussa on jo yleisesti käytössä muitakin tapoja kuin työelämästä eläköitymiskriteerinä pidetty 65 vuotta. Nimityksillä kypsä aikuisuus, myöhäiskeski-ikä tai varhaisvanhuus on pyritty erottamaan aktiivista eläkeläisväestöä varsinaisista vanhuksista, yli 80- tai 85-vuotiaista "supervanhuksista“".

Käytetyt tilastoluokitukset ja säädökselliset ikä- kategoriat ovat merkityksellisiä kuvattaessa yhteiskunnan tilaa mutta myös yksilöt jäsentäessä omaa suhdettaan aikuisuuteen. Aineistossamme omaa aikuisuutta pohdittaessa juridinen täysiikäisyys ja taloudellinen itsenäisyys, jonka perusteeksi opiskelijat mieltävät saamansa opintotuen, nähdään aikuisuuden yleisiksi rajapyykeiksi. Noin neljännes vastaajista myös kokee itsensä aikuiseksi juuri näiden kriteerien täyttymisen perusteella.

\section{Kehityspsykologian aikuinen}

A ikuisuutta on pyritty kategorisoimaan myös psykologisissa ja yhteiskuntatieteellisissä teorioissa, joista merkittävimpiä aikuisuuden määrittymisen kannalta ovat erilaiset ihmisen kehittymistä ja elämänkulkua käsittelevät teoriat. Aikuiskasvatuksen pedagogisissa lähtökohdissa aikuisuuden sisällöt kiinnittyvät pääasiassa niihin teorioihin, joissa ihmisen elämä jaetaan eri vaiheisiin kronologisen iän perusteella jatkumolla lapsuus -nuoruus - aikuisuus - vanhuus. Elämänvaiheteorian klassikoina pidetään Erik Eriksonin identiteetin kehittymistä ja Daniel Levinsonin ihmisen kehitystehtäviä koskevia teorioita, joilla on edelleen vaikutusta ajatteluumme ihmisen elämänkulusta. Erikson kuvaa ihmisen persoonallisuuden kehitystä kahdeksan vaiheen tai psykososiaalisen kriisin avulla. Ihminen kohtaa elämän edetessä uusia sopeutumisvaatimuksia, joita seuraavan kriisin ratkaisu tapahtuu sosiaalisessa kontekstissaan. Elämänvaiheesta riippuen sosiaalinen konteksti on erilainen: lapsuudessa perhe, nuoruudessa koulu ja toveripiiri, aikuisuudessa työelämä. Levinsonin teoria elämänkulusta käsittää vakaiden vaiheiden ja siirtymien vuorottelun. Levinson kuvaa elämää perinteisin metaforin eräänlaisina vuodenaikoina ja näkee vakaiden vaiheiden ja muutosvaiheiden vuorottelussa selvää ikäsidonnaista säännönmukaisuutta. (Perho ja Korhonen 1997,323; Clausen 1986; Durkin 1995.) Vaikka Levinsonin teoriaa on jyrkästi kritisoitukin, siitä löytyvät kuitenkin edelleen aikuisuuden sosiaalipsykologisen määrittelyn ydinseikat: aikuisuuden ydin liitetään niihin rooleihin, joita aikuisella on perheessä ja työssä (Durkin 1995, 598). 
Suomalaisessa kehityspsykologian oppikirjassa (Lyytinen, Korkiakangas \& Lyytinen 1995) käsitellään aikuisuutta nuoruutta seuraavana elämänvaiheena. Aikuisuutta määrittävät ensinnäkin (heteroseksuaaliseksi oletettu) parisuhde tai avioliitto ja vanhemmuus ja toisaalta työelämään siirtymä ja työuralla eteneminen. Kuusinen (1995) lähestyy nuoren kehittymistä aikuiseksi Robert J. Havighurstin kehitystehtäväteorian avulla. Myöhäisnuoruuteen kuuluu emotionaalinen riippumattomuus vanhemmista, parisuhteeseen valmistautuminen, uravalinta, ammattiin valmistautuminen ja yksilöllisen eettisen ja moraalisen uskomusjärjestelmän kehittäminen. Nuoren aikuisen kehitystehtäviin kuuluvat elämäntoverin valitseminen, perheen perustaminen, yhteisen talouden hallinta, työelämään osallistuminen, uralla eteneminen ja kansalaisvelvollisuuksien omaksuminen.

$\mathrm{K}^{\mathrm{e}}$ ehityspsykologian näkökulmasta perhe ja työ vvat keskeisiä määritettäessä aikuiseksi kehittymistä ja täyden aikuisuuden tunnusmerkkejä, kuten Ruoppila $(1995,291)$ toteaa: “Työelämään sïrtymä ja työuralla eteneminen ovat vanhemmuudenohellaaikuisuuden keskeisiäkehitystehtäviä“. Esimerkiksi Koivuluhdan (1999) ammatti-intressejä ja uraa käsittelevässä tutkimuksessa korostuu työn keskeisyys aikuisen elämässä. Tutkimukseen osallistuneet olivat viimeisen seurannan aikana 32-34 -vuotiaita, ja ja tätä ikäkautta on Koivuluhdan mukaan nimitetty laajassa suomalaisessa kehitysseurantatutkimuksessa vakiintuneeksi aikuisuudeksi. Ikäkautta 30 vuodesta eteenpäin on pidetty tärkeänä uran luomisen aikana. Aikaa neljännen vuosikymmenen puolivälissä on kutsuttu myös parhaaksi aikuisiäksi, jolloin elämä on täynnä mahdollisuuksia, mutta toisaalta velvoitteita on runsaasti. Tuolloin parisuhde, lapset, kotitalous ja työura vaativat kaikki runsaasti huomiota ja aika tuntuu loppuvan kesken. (Sinkkonen \& Pulkkinen 1996, 34.)

$\mathrm{E}$ ämänvaiheteorioita on pidetty normatiiviina ja liian ikäsidonnaisina, jotta ne pystyisivät kuvaamaan (post)modernin ihmisen elämää. Elämävaiheiden sijasta onkin alettu puhua elämänkulusta, elämänpoluista ja elämän fragmentoitumisesta $^{2}$. Esimerkiksi Suikkanen ja Lin- nakangas (1998) katsovat työmarkkinoiden muutoksia analysoidessaan, että perinteisen nuoruuden ja aikuisuuden väliiin on muodostumassa 510 vuoden elämänvaihe, joka sisältää epämääräistä opiskelun, palkkatyön, työttömyyden ja työmarkkinoiden ulkopuolella olemisen vuorottelua. Myöskään koulutus ei kaikilla sijoitu aikaan ennen työuran aloittamista, vaan se voi olla työssäkäynnin kanssa limittäistä tai päällekkäistä ja yksilön perhestatus ja -muoto saattavat vaihtua tiuhaankin. Aapola $(1999,32)$ toteaakin, että nuoruudeksi nimitettävä ajanjakso piteni 1900-luvulla molemmista päistään, koska toisaalta nuorten fyysinen kehitys on jatkuvasti aikaistunut, mutta toisaalta opiskelua jatketaan pitempään kuin aikaisemmin. Taloudellisen itsenäisyyden saavuttaminen on nykypäivän nuorille yhä pidempi ja monimutkaisempi prosessi. Nuoruuden ja aikuisuuden ja toisaalta aikuisuuden ja vanhuuden välinen rajanveto on yhä "vaikeampaa“: yhä useammin valinnat esimerkiksi työn, koulutuksen tai perheen suhteen ovat yksilöllisiä limittyen kunkin omaan elämänhistoriaan. Aineistossamme kuitenkin näkyi, että perheellisyyden koetaan vastaajan iästä riippumatta merkitsevän väistämätöntä aikuisuutta: "pakko olla [aikuinen] kun on omia lapsia“.

\section{Aikuiset suomalaisessa koulutus järjestelmässä}

Aikuiskoulutuskomitea nosti käsitteen aikuiskoulutus viralliseksi yleiskäsitteeksi määritellessään sen tarkoittamaan kaikkia aikuisille tarkoitettuja ohjattuja oppimistilaisuuksia. Tämä lähtökohta ohjaa edelleen aikuiskoulutuksen määrittelyä. Esimerkiksi Tilastokeskuksen tilastoimat tiedot aikuisopiskelusta koskevat "vähintään kuusi tuntia kestävää opintolinjaa, kurssia tai koulutusohjelmaa, joka on suunniteltu aikuisille" (Tilastokeskus 1997, 35). Teos Aikuisopiskelu Suomessa (Blomqvist, Koskinen, Niemi \& Simpanen 1997) perustuu 18-64-vuotiasta väestöä koskevaan otokseen (jolloin aikuisväestö määrittyy eri kriteerillä kuin työikäinen väestö). Teoksessa aikuisten opiskelu luokitellaan aikuiskoulutukseksi ja koulujärjestelmäkoulutukseksi. Koulujärjestel- 
mäkoulutukseksi katsotaan pääsääntöisesti nuorille suunniteltu koulutus lukioissa, ammatillisissa oppilaitoksissa ja korkeakouluissa.

Suomalaisessa koulutuspolitiikassa varsinaisista kelijan määrittelyssä on käytössä institutionaalinen peruste: aikuisille erikseen järjestetty koulutus on aikuiskoulutusta. Aikuisuus ymmärretään tällöin ilmeisesti yksilön aiemman työelämäsuhteen ja ammatillisen koulutuksen tai niiden puuttumisen avulla. Institutionaalista määrittelyä käytettäessä on siten vaikeaa löytää tai erotella "aikuisopiskelijaa" traditionaalisessa merkityksessä: opiskelijaa, joka opiskelee oppimisen itsensä vuoksi ilman tavoiteltavaa hyvitystä tai statusta, sillä monet aikuisoppilaitokset tarjoavat nimenomaan tutkintoon johtavaa koulutusta. Instituution perusteella tapahtuva määrittely rajaa joka tapauksessa aikuisopiskelijoista pois iän ja työmarkkina-aseman perusteella aikuisiksi määrittyvistä ne, jotka opiskelevat pääasiassa nuorille suunnatussa koulutuksessa. Tähän viittaa myös muutos lakiin ammatillisesta koulutuksesta, josta on poistettu maininta aikuisille erikseen tarkoitetuista opintomuodoista (L 630/1998; Kilpeläinen 2000). Blomquistin et al. (1996) tutkimuksessa todetaan, että yhteensä 380000 henkilöä eli 12 prosenttia 18-64-vuotiaasta väestöstä opiskelee koulujärjestelmäkoulutuksessa eikä heitä siten ole luokiteltu aikuisopiskelijoiksi. Käytetty ikäluokitus vaikeuttaa mahdollisuutta arvioida aikuisten, esimerkiksi jo työelämässä olleiden opiskelua koulujärjestelmäkoulutuksessa, onhan suuri osa alle 20 -vuotiaista selvästi vielä ensimmäisessä koulutuksessaan kuulumatta siten aikuiskoulutuksen institutionaalisen määritelmän sisään. Aikuiskoulutukseen siirrytään määritelmällisesti vasta toisen ammatillisen koulutuksen hankkimisen yhteydessä, mikäli koulutus tapahtuu aikuisoppilaitokseksi nimetyssä organisaatiossa.

Nykyisen koulutuspolitiikan tavoitteeksi asetetaan selkeästi ja yhdenmukaisesti koko väestön osaamistason nostaminen (ks. esim. Elinikäisen oppimisen komitea 1997; Elämänlaatu, osaaminen ja kilpailukyky 1998; Aikuiskoulutuspolitiikka 1999; Opetusministeriö 2000). Toimin- ta rakentuu kokonaisuudessaan analyyseille kiihtyvästä muutoksesta, joka edellyttää elinikäisen oppimisen teoriaan sisältyvien käytäntöjen toteutumista, ja yhtäläiset koulutusmahdollisuudet halutaan taata kaikille iästä riippumatta. Vaikka julkisessa retoriikassa ikäkategorioista on suuressa määrin luovuttu, eroa eri ikäisten oppijoiden välille rakennetaan myös uudessa koulutuksen ja tutkimuksen kehittämissuunnitelmassa, jossa määrittyy erillinen asema aikuisille. Nuorille suunnattujen aloituspaikkojen lisäksi "erilaisia pohjakoulutuksia omaavien aikuisten tutkintoon johtavaan peruskoulutukseen osoitetaan sekä toisen asteen koulutuksessa että ammattikorkeakouluissa ja yliopistoissa 10-20 prosenttia koulutustarjonnasta.“

Koulutukseen liittyvä kansainvälistyminen rakentaa myös eroja nuorten ja aikuisten välille. Kehityssuunnitelmassa todetaan, että "suomalaisille nuorille luodaan hyvät ja joustavat mahdollisuudet itsensä kehittämiseen ja opiskeluun ulkomailla“. Koska kansainvälistä kokemusta ja opiskelua ulkomailla arvostetaan useimmilla työelämän alueilla (Opetusministeriö 1997, 9), opiskelija voi kasvattaa tutkintonsa arvoa kansainvälisen harjoittelun avulla tai opiskelemalla ulkomaisessa oppilaitoksessa. Kansainvälistyminen on nuorelle opiskelijalle helpompaa kuin aikuiselle ainakin kahdesta syystä. Ensinnäkin aikuisten hakeutumista ulkomaille vaikeuttavat perhevelvollisuudet, onhan aikuinen opiskelija nuorta useammin perheellinen (vrt. Korhonen 1998, 284). On myös yleinen käytäntö, että yhtiöt ja instituutiot hakevat alle 30-vuotiaita harjoittelijoita ja apuraha-opiskelijoita.

\section{Aikuiskasvatus ja moraalisesti kypsä aikuisuus}

oulutuksen ja työelämän määritysten ohella
aikuisuus voidaan nähdä myös kategoriana, jossa yksilön moraalisen kasvun sisällöt ovat merkityksellisiä. Etenkin aikuiskasvatuksen traditiossa aikuisuus on sidoksissa yksilön eettisiin ja moraalisiin ominaisuuksiin. Malcolm Tight (1996, 13-14) määrittelee aikuisuutta olemisena, jossa yksilö saavuttaa oikeuksia ja tietyn statuksen, 
mikä samalla asettaa hänelle velvoitteita ja vastuuta. Aikuisuus perustuu oletuksille moraalisesta kypsyydestä. Tightin määrittely näyttää yhtyvän aikuiskasvatuksen historialliseen tapaan mieltää aikuisuus. Humanistis-kristillisen tradition puitteissa aikuisuus ei kytkeytynyt ikään vaan ihmisen moraaliseen tilaan. Suomessa tätä ajatusta kehitti keskeisesti Urpo Harva. Harva katsoi, että ihmisen kasvu on elinikäinen prosessi, jossa vasta aikuisuudessa alkaa esimerkiksi moraaliseen vastuuntuntoon kiinnittyvän rakkauselämän lisäksi varsinainen eettisen kasvamisen kausi: "Sosiaalisen mielen kasvu täydessä rikkaudessansa, jolloin siihen kuuluu runsaita tietoja, yhteiskunnallista viisautta, oikeudenmukaisuutta ja vastuuntuntoa, tapahtuu sekin vasta aikuisiässä “. Harva pitää mahdollisena, että vasta vanhuusikään sijoittuu uskonnollisen elämän kasvu (Harva 1942, 12-13) eikä ihminen siten ole koskaan "valmis". Harva kritisoi ajattelua, jossa lähdetään siitä, että " $k e$ hityksen lakipiste on saavutettu. Muutoksen aikaansaamista ei pidetä tarpeellisena; päinvastoin monia aikuisia ihaillaan taitavina työläisinä, vastuuntuntoisina toimihenkilöinä, uhrautuvina äiteinä‘.(Harva 1968, 91) Hän painottaa, että aikuisiin kohdistuvan kasvatuspyrkimyksen sisältö liittyy pitkälti ihmisen henkisyyteen, joka syvenee mitä pidemmälle aikuisikään tullaan. Kasvattajan tulee herättää kasvattinsa "syvempään moraaliin, kääntää hänenmieltään pinnallisestaja vähäarvoisesta todellisten arvojen suuntaan, saada hänet syntymään uudestaan. "Tällöin aikuisten kasvattamisessa on tärkeää, että kansansivistystyö "ei hyväksy ihmistä sellaisena kuin hän tässä ja nyt on, se pitää ihmistä epävalmiina, kehitystäjajalostamista tarvitsevana“ (Harva 1948, 49).

A ikuiskasvatuksen historia kiinnittyykin "uudelleen syntymisen" tai "heräämisen“" problematiikkaan määrittäessään täysivaltaista aikuista ihmistä. Modernin valistuksen projektissa kristillinen "herätys" yhtyy sekä kantilaiseen itseaiheutetusta alaikäisyydestä "heräämiseen“ että snellmanilaiseen kansakunnan synnyttämiseen. Lähtökohtana aikuisuuden määrittymiselle on tällöin, että ihminen ei ole aikuinen ennen tietoista ymmärrystä omasta moraalisesta laadustaan ja suhteestaan toisiin, ilman pyrkimystä johonkin "suurempaan" kuin mitä pelkkä yhteiskun- nallinen täysi-ikäisyys sinänsä edellyttää. 1900luvun alussa Niilo Liakka (1908) asetti tämän pyrkimyksen kolmivaiheiseksi ohjelmaksi, jossa "kehityksen kulkuonoleva: sisäänpäin persoonalliseen kehitykseen, itsenäisyyteen, omantakeisen vakaumuksen etsimiseen, ylöspäin pois itsekkäisyydestä, oman edun tavoittelusta, alistumaan voimille ja tarkoitusperille, jotka ovat suurempia kuin itse, tunnustamaan Jumalan isällistä voimaa, joka tekee heikon väkeväksi, sitten vasta eteenpäin hyödylliseen ja hedelmälliseen toimintaan omaksi hyväksi sekä myös edistämään yhteistähyvää. “

$I^{\mathrm{n}}$ hmisen henkistä kasvua ja kypsyyttä korostavan aikuisuuden ymmärtäminen poikkeaa ajattelusta, joka sisältyy ikäkategoristen kehitystehtävien normatiivisiin lähtökohtiin. Se ei myöskään liity koulutus- ja työmarkkinoihin eikä sosiaalivaltiolliseen sääntelyyn, vaan yksilön suhteeseen omaan moraaliinsa ja sen yhteisöllisiin merkityksiin. Tässä ideaalissa aikuinen erottuu ei-aikuisesta kyvyssään yhdistää henkilökohtaisen onnensa pyrkimys yhteisöllisen hyvän saavuttamiseen. Aikuiskasvatuksen teoriahistoriallisesta näkökulmasta aikuisuuteen sisältyy käsitys jatkuvasta oppimisesta sekä sen itsensä että yhteisen hyvän vuoksi ilman ulkoista hyvitystä tai statusta. Tällaisenaan aikuiskasvatus on yhtä hyvin yhteiskunnallinen liike kuin koulutusinstituutio. (Tight 1996, 59-64.)

Jos jälkimodernin yhteiskunnan aikuisuutta tarkastellaan ei-institutionaalisesta perspektiivistä, sen sisältöihin näyttää ainakin osittain syntyneen uusia, yksilön moraalisuutta korostavia tendenssejä. Moraaliset kysymykset ovat keskeisiä myös aineistomme opiskelijoiden vastauksissa heidän pohtiessaan aikuisuuden sisältöä: kolme neljäsosaa vastaajista liittää aikuisuuteen vastuuntunnon ja vastuullisuuden omista teoistaan, jonkin verran harvempi myös vastuun toisista ihmisistä. Moraalia koskevissa analyyseissa päädytäänkin lähes systemaattisesti yksilöön moraalin tärkeimpänä kantajana. Yksilöllinen moraali edellyttää jokaiselta korkeaa eettistä tietoisuutta, sillä yksilöiden suhteet muodostuvat kahdenvälisistä, vaihtuvista ja muutettavista sopimuksista. Moraali saa samankaltaisia sisältöjä myös uusyhteisöllisyyttä analysoivissa teorioissa, joissa yhtei- 
söihin kuuluminen on hetkittäistä, vaihtuvaa ja emotionaalista, yhteisöllisen moraalin sitovuuden jäädessä heikoksi (esim. Maffesoli 1996). Moraalin yksilölähtöisyyden paradoksaalisuutta yrittää ratkaista esimerkiksi Bauman (1996) esittäessään ohjelman, jossa todellinen moraali voisi todentua vain välittömissä vuorovaikutussuhteissa, jolloin toimijat tuntevat vastuuta toisistaan. Bauman katsoo, että osallistuva ja empaattinen asenne toista kohtaan on aina persoonallinen ja säännötön eikä sitä voi opettaa ulkoläksynä, sillä opettamisessa ja oppimisessa ei ole tilaa empatialle ja emotionaaliselle osallistumiselle. Vain henkilökohtaisella sitoutumisella toisen hyvään voidaan saavuttaa eettisyys.

$\mathrm{B}$ aumanin ajatus yksilöllisen etiikan ihanteesa tulee lähelle elinikäisen oppimisen ja oppimisyhteiskunnan ideaaleja. Niissä oppiminen nähdään yksilön yhteiskunnallisesti vastuulliseksi teoksi ja valinnaksi, jonka tarkoituksena on sekä persoonallinen kehitys että yhteiskunnan demokraattisten rakenteiden vahvistaminen. Vaikka elinikäinen oppiminen kiinnittyy osin institutionaaliseen aikuiskoulutukseen, oppimisyhteiskunnan ideaalin ytimessä korostuu yksilön moraali: oppiminen lisää suvaitsevaisuutta, toisten yksilöiden, kulttuurien ja traditioiden ymmärrystä ja kunnioitusta ja suuntautuu yksilön sisäisestä kehityksestä yhteisölliseen hyvään (esim. Coffield 1997, Raggatt et. al 1996).

Oppimisyhteiskunta korostaa aikuisuutta vastuullisuutena, kypsinä valintoina ja henkilökohtaisena kasvuna, ja myönteisenä asenteena "älyllistä, esteettistä, moraalista ja sosiaalista kasvua kohden “ (Komiteamietintö 1997). Siten esimerkiksi Baumanin ajatus moraalisen toiminnan perustasta, joka ei ole opetettavissa, asettuu lähelle oppimisyhteiskunnan informaalia, osallistuvaa ja oppivaa yhteisöllisyyttä, joka kattaa koko elämän. Se sisältää myös ne teoreettisen keskustelun lähtökohdat, joissa ihmisen ei nähdä tulevan elämässään koskaan valmiiksi, mutta keskeneräisyyden nähdään edellyttävän jatkuvien oppimisvalintojen tekemistä ja siten oppimisyhteiskunnan vahvistumista. Hoikkala ja Roos (2000) kuvaavatkin ihmisen suhdetta toimintoihinsa jälkimodernissa yhteiskunnassa todeten "elämänpolitii- kan“ ideaalin merkitsevän ajatusta jatkuvista elämän uusista aluista, ihmisenä kasvamisesta ja toisista mahdollisuuksista.

\section{"Uusi aikuisuus”}

"Toinen mahdollisuus" on aikuiskoulutuspolitiikan ydintä. Aikuisuuden perspektiivistä se tarkoittaa siirtymiä riippumattomasta työmarkkinakansalaisuudesta opintotukisäädöksistä riippuvaisiin opiskelijan asemiin ja takaisin. Aikuisten opiskelu voi tapahtua myös työn ja opiskelun suhteen sitovassa kaksoispositiossa: työmarkkinakansalaisuudesta ei luovuta, vaan opiskelu tapahtuu työn ohella. Aikuisten hakeutumista ja osallistumista koulutukseen voidaan tarkastella aikuisikää koskevan diskurssin muutoksena. Koko eliniän jatkuvaa koulutusta on alettu pitää yhtenä tärkeänä (joskus jopa ainoana) tienä täysivaltaiseen aikuisuuteen. Jälkimoderneissa yhteiskunnissa aikuisikään kuuluu vaateita persoonallisuuden kehittämisestä, henkilökohtaisesta kasvusta ja itsensä toteuttamisesta, kun aikanaan tasapaino haettiin vakaista sosiaalisista rakenteista, kuten perheestä ja työelämästä (Hepworth 1987). Hepworth näkee, että on tarpeen luoda uusia ajattelumalleja aikuisiän hahmottamiseen. Mahdollisuudet erilaisille ja eriytyville elämänkuluille ovat avoimempia ja joustavampia kuin aiemmin. Kyse on "uudesta aikuisuudesta" kontrastina aikuisuus ymmärtämiseen tasaisena elämänvaiheena, johon liittyy elämän tasapainoisuus, harmonisuus ja pysyvyys. Muutos "uuteen aikuisuuteen" on ollut vähittäinen, eivätkä kaikki koe aikuisuuden uusia vaateita velvoittavina. Aikuisuutta on mahdollista elää monin eri variaatioin.

Puheet elinikäisestä oppimisesta, oppimisyhteiskunnasta ja jatkuvan koulutuksen tärkeydestä voidaan nähdä "pakottavana" diskurssina (esim. Silvennoinen, Tulkki \& Honkanen 1998), jolloin yksilön menestyäkseen tai ylipäätään säilyäkseen yhteiskuntakelpoisena on toistuvasti hakeuduttava koulutukseen. Myös Schueller ja Field (1998) näkevät oppimisyhteiskunnan yhteiskuntana, jossa opiskellaan yhä enemmän ja yhä pitempään ja jossa oppiminen esittäytyy välttämättömyytenä - täysivaltaisen aikuisuuden määrittäjänä? 


\section{Aikuisuuden ja aikuis- kasvatuksen rajojen

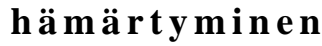

A ikuisuus näyttää sekä pidentyneen että lyhentyneen, tulleen sekä täydemmäksi että tyhjemmäksi riippuen siitä, katsotaanko sitä institutionaalisesta vai kulttuurisesta näkökulmasta, ja siitä, minkälainen yhteiskunnallinen ideaali tarkasteluun valitaan. Ihmisten elämänkulku ja valinnat sekä työelämän, perhe-elämän että formaalin koulutuksen alueella osoittavat, että kehityspsykologian ja erilaisten säädösten normittaman elämänkulun ylitykset ovat mahdollisia ja yleisiä. Nuoruudessa hankitun ammatin ja työn voi hyvin jättää esimerkiksi 40 vuoden iässä ja lähteä opiskelemaan - eikä välttämättä aikuiskoulutukseen vaan varsin luontevasti myös koulujärjestelmäkoulutukseen. Nykyisin myös opiskellaan entistä kauemmin ja on entistä hankalampaa erottaa aikuiskoulutus tarkasti omaksi alueekseen (vrt. Rinne et al. 1991, 40). Yksi uusi aikuisiän toimintamahdollisuus on opiskelu paitsi perinteisissä, aikuisille suunnatuissa koulutusmuodoissa myös nuorille suunnatussa koulutuksessa (ks. Moore 2000). Samalla aikuiskoulutukseen osallistuminen näyttää yhä enemmän kiinnittyvän työelämään ja ammattiin tai sukupuoleen, ei opintojen sisältöön (esim. Antikainen ja Kauppila 2000).

Kun tarkastellaan lainsäädäntöä, koulutusjärjestelmää ja työelämän käytäntöjä, aikuisuus saa toisistaan poikkeavia kriteereitä. Aikuisuus ei ole yksiselitteinen ikävaihe tai selkeä siirtymä elämänkulussa. Historiallisessa perspektiivissä aikuisuuden, samoin kuin muiden ikävaiheiden rajaamisen tarve liittyy institutionaalisen normiohjauksen syntyyn. Koulutuksen kannalta aikuisuuden erillinen määritys on siten varsin uusi ongelma, jota aikuiskasvatuksen tai kansansivistystyön varhaisessa teoriakehittelyssä ei näytä olleen välttämätöntä tai edes tarpeellista pohtia. Nyt ollaan kuitenkin tilanteessa, jossa on perusteltua kysyä, miten aikuiskasvatuksen aikuis-etuliite eriyttää sitä omaksi alueekseen? Kun elinikäinen oppiminen sisältää kaikki ihmisen elämäntapahtumat ja toiminnan alueet, kysymykseksi tulee miten aikuisuus sinänsä määrittyy eril- liseksi koulutuksen tai kouluttautumisen kontekstikseen?

\section{Viitteet}

1 Empiiristä aineistoa ovat eri oppilaitoksissa ja eri koulutusasteilla opiskelevien näkemykset aikuisuudesta. Analysoitu aineisto käsittää kahdella yliopiston eri peruskurssilla toteutetun kyselyn vastaukset. Kyselyyn vastasi yhteensä 137 opiskelijaa syksyllä 2000. Kyselyssä opiskelijoita pyydettiin vastaamaan lyhyesti kysymyksiin "Mitä on aikuisuus? Minkälainen on aikuinen?" ja "Oletko itse aikuinen? Perustele vastauksesi.“

Elämän luonnetta on kuvattu myös esimerkiksi seuraavilla kielikuvilla: vuorottelu, syklisyys, portaisuus ja limittäisyys.

\section{Lähteet}

AAPOLA, S. (1999) Murrosikä ja sukupuoli. Julkiset ja yksityiset ikämäärittelyt. Helsinki: Suomalaisen Kirjallisuuden Seura.

AIKUISKOULUTUSPOLITIIKKA 2000-luvun alkuvuosina (1999). Aikuiskoulutusneuvoston julkaisuja 16. Helsinki.

ANTIKAINEN, A. \& KAUPPILA, J. (2000) Oppivan ihmisen kertomus: Koulutussukupolvet ja vapaan sivistystyön tulevaisuus. Aikuiskasvatus 20(1): 1222.

ANTIKAINEN, A.; RINNE, R. \& KOSKI, L. (2000) Kasvatussosiologia. Helsinki: WSOY.

BAUMAN, Z. (1996) Life in Fragments. Essays in Postmodern morality. Oxford \& Cambridge: Basil Blackwell.

BLOMQVIST, I.; KOSKINEN, R.; NIEMI, H. \& SIMPANEN, M. (1997) Aikuisopiskelu Suomessa. Aikuiskoulutustutkimus 1995. Tilastokeskus, Koulutus 1997:4

CLAUSEN, J. A. (1986) The life course: a sociological perspective. Englewood Cliffs: N.J. Prentice-Hall.

COFFIELD, F. (1997) Introduction and overview: attempts to reclaim the concept of the learning society. Journal of Education Policy 12 (6): 449455 .

DURKIN, K. (1995) Developmental Social Psychology. From infancy to old age. Padstow: Blackwell Publishers.

ELÄMÄNLAATU, OSAAMINEN JA KILPAILUKYKY. (1998) Tietoyhteiskunnan strategisen kehittämisen lähtökohdat ja päämäärät. Sitra 206. Helsinki: Hakapaino.

HARINEN, P. (2000) Valmiiseen tulleet. Tutkimus nuoruudesta, kansallisuudesta ja kansalaisuudesta. Nuorisotutkimusverkosto, Nuorisotutkimusseura Julkaisuja 11/2000. Helsinki: Hakapaino Oy.

HARVA, U. (1942) Kansansivistystyön käsite. Vapaa kansansivistystyö. Kansansivistysopillisen yhdistyksen vuosikirja 1942. Helsinki: Kansansivistysopillinen yhdistys. 3-17.

HARVA, U. (1948) Kansansivistäjä. Helsinki: Otava.

HARVA, U. (1968) Systemaattinen kasvatustiede. Helsinki: Otava. 
HEPWORTH, M. (1987) The mid life phase. Teoksessa Cohen, Gaynor (toim.): Social Change and the Life Course. Cambridge: Tavistock Publications.

HOIKKALA, T. \& ROOS, J-P. (2000) Onko 2000-luku elämänpolitiikan vuosituhat? Ss. 9-31 teoksessa Hoikkala, T. ja Roos, J-P. (toim.) 2000-luvun elä-

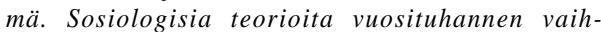
teesta. Helsinki: Gaudeamus.

ILTASANOMAT 27.5.2000. "En tunne itseäni tippaakaan keski-ikäiseksi“. ss. A22-23.

KANSALLINEN IKÄOHJELMA (2000) Opetusministeriön toimenpiteet 1999-2000. Opetusministeriön ikäohjelman työryhmän raportti.

KILPELÄINEN, A. (2000) Naiset paikkaansa etsimässä. Aikuiskoulutus naisen elämänkulun rakentajana. Jyväskylä Studies in Education, Psychology and Social Research 163. Jyväskylä.

KOIVUlUHTA, M. (1999) Ammatti-intressit ja ura. Pohjoiskarjalaisen ammattikoulutetun ikäluokan seuranta vuosina 1975-1991. Joensuun yliopiston yhteiskuntatieteellisiä julkaisuja, nro 42. Joensuu: Joensuun yliopistopaino.

KOMITEANMIETINTÖ (1971) Aikuiskoulutuskomitean I osamietintö. A 29. Helsinki.

KOMITEANMIETINTÖ (1975) Aikuiskoulutuskomitean II osamietintö. A 28. Helsinki.

KOMITEANMIETINTÖ (1997) Oppimisen ilo. Elinikäisen oppimisen strategia. KM 1997:14 Helsinki:Edita.

KORHONEN, M. (1998) Perheellinen opiskelija - kohtalaisen adaptiivinen optimisti. Kasvatus 29(3): 280-287.

KUUSINEN, J. (1995) Nuorten aikuisten kehitystehtävät, onnellisuus ja kehityksen hallinta. Ss. 311322 teoksessa Lyytinen, P.; Korkiakangas, M. \& Lyytinen, H. (toim.): Näkökulmia kehityspsykologiaan: kehitys kontekstissaan. Porvoo: WSOY.

L 65/1994. Opintotukilaki.

L 665/1996. Laki työmarkkinatuesta annetun lain muuttamisesta.

L 630/1998. Laki ammatillisesta koulutuksesta.

LIAKKA, N. (1909) Kansanopisto-opetuksen rajoittamisesta "kipeimmin kaivattuun". Pyrkijä 8.

LYYTINEN, P.; KORKIAKANGAS, M. \& LYYTINEN, H. (toim.) (1995) Näkökulmia kehityspsykologiaan: kehitys kontekstissaan. Porvoo: WSOY.

MAFFESOLI, M. (1996) The Time of the Tribes. The Decline of Individualism in Mass Society. London, Thousand Oaks, New Delhi: SAGE Publications.

MOORE, E. (2000) Aikuisena yliopistossa. Yliopistoopiskelijoiden ikärakenne ja 30 vuotta täyttäneiden opiskelijoiden elämänkulku. Saarijärvi: Joensuu University Press.

NIKANDER, P. (1999) Elämänkaaresta elämänkulkuun: iän muuttuva merkitysmaailma. Teoksessa: Kangas, Ilka \& Nikander, Pirjo: Naiset ja ikääntyminen. Tampere: Gaudeamus.

NUORISOBAROMETRI 1/1999. NUORAn julkaisuja nro 13. Helsinki.

OPETUSMINISTERIÖ (1997) Tutkijanuran kehittämistyön muistio. Opetusministeriön työryhmien muistioita 5. Helsinki: Yliopistopaino.

OPETUSMINISTERIÖ (1998) Koulutuspolitiikasta elinikäisen oppimisen edistämispolitiikkaan. Elinikäisen oppimisen hankkeen loppuraportti. Opetusministeriö: Koulutus- ja tiedepoliittinen osasto.
OPETUSMINISTERIÖ (2000) Koulutus ja tutkimus vuosina 1999-2004. Kehittämissuunnitelma. Helsinki: Edita.

PERHO, H. \& KORHONEN, M. (1995) Siirtymien sijoittuminen ja sisältö varhaisaikuisuudessa. Ss. 323324 teoksessa Lyytinen, P.; Korkiakangas, M. \& Lyytinen, H. (toim.): Näkökulmia kehityspsykologiaan: kehitys kontekstissaan. Porvoo: WSOY.

RAGGATT, P.; EDWARDS, R. \& SMALL, N. (1996) Introduction: from adult education to a learning society? Ss.1-9 teoksessa: Raggatt, P., Edwards, R. \& Small, N. (eds.) The Learning Society. Challenges and Trends. London and New York: Routledge.

RINNE, R.; KIVINEN, O. \& NAUMANEN, P. (1991) $A i-$ kuiskoulutuksen yhteiskunnalliset lähtökohdat. Avoimen korkeakouluopetuksen julkaisuja. Turun yliopiston täydennyskoulutuskeskus. Turku: Painosalama.

RUOPPILA, I. (1995) Johdanto. Ss. 290-296 teoksessa Lyytinen, P.; Korkiakangas, M. \& Lyytinen, H. (toim.): Näkökulmia kehityspsykologiaan: kehitys kontekstissaan. Porvoo: WSOY.

SCHUELLER, T. \& FIELD, J. (1998) Social capital, human capital and the learning society. International Journal of Lifelong Education 17 (4): 226235.

SILVENNOINEN, H.; TULKKI, P. \& HONKANEN, P. (1998) Kansalaiset elinikäisen oppimisen kourissa. $F u$ tura (1): 64-70.

SINKKONEN, M. \& PULKKINEN, L. (1996) Elämänrakenne parhaassa aikuisiässä. Jyväskylän yliopiston psykologian laitoksen julkaisuja 333. Jyväskylä: Jyväskylän yliopistopaino.

SUIKKANEN, A. \& LINNAKANGAS, R. (1998) Uusi työmarkkinajärjestys? Sitra 182. Helsinki.

TIGHT, M. (1996) Key Concepts in Adult Education and Training. St. Ives: Routledge.

TILASTOKESKUS (1997) Oppilaitostilastot 1997. SVT Koulutus 1997:5. Helsinki.

TILASTOKESKUS (1999a) Perheet 1998. Väestö 1999:12. Helsinki.

TILASTOKESKUS (1999b) Työvoimatilasto 1998. Työvoimatutkimuksen tuloksia vuosilta 1989-1998. SVT Työmarkkinat 1999:21.

TOIVIAINEN, T. (toim.) (1997) Aikuiskasvatus: avain XXI:n vuosisadan haasteisiin. Unescon viides aikuiskasvatuksen maailmankonferenssi ja sitä edeltänyt Suomen kansallinen seminaari. Helsinki: Vapaan sivistystyön yhteisjärjestö.

TUOMISTO, J. (1991) Aikuiskasvatuksen peruskäsitteen historiallinen kehitys. Teoksessa: Valistus, sivistys, kasvatus. Kansanvalistuksesta aikuiskasvatukseen. Vapaan sivistystyön vuosikirja 32. Helsinki: Kansanvalistusseura.

VILKKO, A. (1997) Omaelämäkerta kohtaamispaikkana. Naisen elämän kerronta ja luenta. Helsinki: Suomalaisen Kirjallisuuden Seura.

www.kela.fi (2000) Aikuisopintotuki. http:// www.kela.fi/opintotuki/esite8.htm. 16.10.2000.

www.stat.fi (2000) Luokitusopas. http://www.stat.fi/ tk/tt/luokitukset/opas.html\#k314. 16.10.2000.

Artikkeli saapui toimitukseen 26.10.2000. Se hyväksyttiin julkaistavaksi toimituskunnan kokouksessa 5.2.2001. 